\title{
Manajemen Asuhan Kebidanan Intranatal Berkelanjutan pada Ny "M" dengan Preeklampsia Berat di RSUD Syekh Yusuf Kabupaten Gowa Tanggal 15 Oktober - 21 November 2018
}

\author{
${ }^{1}$ Kasnur, ${ }^{2}$ Firdayanti, ${ }^{3}$ Rauly Rahmadhani
}

\begin{abstract}
ABSTRAK
Pendahuluan preeklampsia merupakan komplikasi kehamilan dan persalinan yang ditandai dengan peningkatan tekanan darah, proteinuria dan oedema, yang kadang-kadang disertai dengan komplikasi koma.Gejala dari preeklampsia seperti hipertensi, oedema dan proteinuria sering tidak diperhatikan, sehingga tanpa disadari dalam waktu singkat dapat timbul menjadi preeklampsia berat, bahkan eklampsia.
\end{abstract}

*UIN Alauddin Makassar

Metode Jenis penelitian ini adalah studi kasus dengan pendekatan Manajemen Asuhan Kebidanan Intranatal Berkelanjutan pada $\mathrm{Ny}$ "M" dengan Preeklampsia Berat di RSUD Syekh Yusuf Kabupaten Gowa Tahun 2018 sesuai Manejemen Asuhan Kebidanan 7 langkah Varney dan pendokumentasian dalam bentuk SOAP.

Hasil Penatalaksanaan Asuhan Persalinan dengan preeklampsia berat pada Ny "M" yaitu dilakukan pemberian asuhan yang sesuai standar operasional prosedur serta melakukan upaya pencegahan komplikasi dengan pemberian Magnesium Sulfat untuk mencegah terjadinya eklampsia, HELLP Sindrom, solusio plasenta, gangguan organ, KJDR pada bayi serta dilakukannya pemantauan dan Asuhan Manejemen Kebidanan dari kala I sampai kala IV.

Kesimpulan dari kasus yaitu diantaranya pendokumentasian dalam bentuk SOAP yang digunakan untuk proses penyelesaian masalah kebidanan telah dilaksanakan pengkajian serta asuhan dengan penatalaksanaan yang sesuai pada Ny "M" dengan preeklampsia berat di RSUD Syekh Yusuf Kabupaten Gowa Tahun 2018 yakni dari kala I sampai kala IV, tidak ditemukannya komplikasi pada ibu dan bayi.

Kata kunci :

Preeklampsia Berat;

7 Langkah Varney

\section{PENDAHULUAN}

Preeklampsia berat merupakan komplikasi kehamilan dan persalinan yang ditandai dengan peningkatan tekanan darah, proteinuria dan oedema, yang kadang-kadang disertai dengan komplikasi koma.Gejala dari preeklampsia seperti hipertensi, oedema dan proteinuria sering tidak diperhatikan, sehingga tanpa disadari dalam waktu singkat dapat timbul menjadi preeklampsia berat, bahkan eklampsia (Sarwono, 2014: 532). 
Gambaran klinik preeklampsia bervariasi luas dan sangat individual. Kadang-kadang sukar untuk menentukan gejala preeklampsia mana yang timbul lebih dahulu.Secara toritik urutan-urutan gejala yang timbul pada preeklampsia ialah edema, hipertensi, dan terakhir protein merupakan gejala yang paling penting.Namun sayangnya penderita sering kali tidak merasakan perubahan ini.Bila penderita sudah mengeluh adanya gangguan penglihatan, atau nyeri epigastrum, maka penyakit ini sudah cukup lanjut (Sarwono, 2014).

Ibu yang mengalami komplikasi - komplikasi pada persalinan salah satunya preeklampsia berat.Preeklampsia berat adalah preeklampsia dengan tekanan darah sistolik $\geq 160 \mathrm{mmHg}$ dan tekanan darah diastolik. $\geq 110 \mathrm{mmHg}$ disertai proteinuria lebih dari +2 (Sarwono, 2014). Dampak preeklampsia pada ibu yaitu kerusakan organ-organ tubuh seperti :sistemsaraf pusat, perdarahan intrakranial,solusio plasenta gagal jantung, gagal ginjal, gangguan fungsi hati dan edema paru, sedangkan pada janin ialah intrauterine fetal growthrestriction,prematur, sindroma distress, kematian janin, kematian neonatal, perdarahan intraventikular (Sarwono, 2014:550).

Penanganan pada preeklampsia bertujuan untuk menghindari kelanjutan menjadi eklampsia dan pertolongan dengan melahirkan janin dalam keadaan optimal dan bentuk pertolongan dengan trauma minimal. Sebagaimana penelitian yang dilakukan Suresh Candra Mondal, dkk di India tentang dosis profilaksis awal MgSO4 pada preeklampsia berat untuk memperbaiki keadaan ibu dan perinatal mengatakan dosis awal Magnesium sulfat dapat mencegah perinatal dan kematian ibu. Jadi profilaksismagnesium sulfat (MgSO4) harus dimulai pada titik kontak pertama dengan penyedia kesehatan yang terlatih (Suresh, dkk, 2014).Faktor yang mempengaruhi preeklampsia salah satunya paritas yaitu primigravida, terutama primigravida muda.Pada primipara atau ibu yang pertama kali melahirkan faktor resiko terjadinya preeklampsia lebih tinggi dibandingkan dengan multipara dan grandemultipara. Pada primipara sering mengalami stress dalam menghadapi persalinan sehingga dapat terjadi hipertensi dalam kehamilan atau terjadinya preeklampsia atau eclampsia (Anita, 2016).

Preeklampsia tidak dapat dicegah, yang terpenting adalah bagaimana penyakit ini dapat dideteksi sedini mungkin. Deteksi pada saat pemeriksaan tekanan darah secara rutin pada saat pemeriksaan kehamilan (antenatal care). Karena itu pemeriksaan kehamilan rutin mutlak dilakukan agar preeklampsia dapat dideteksi cepat untuk meminimalisir kemungkinan komplikasi yang fatal (Ai Yeyeh Rukiyah, 2010). Sebagaimana penelitian yang dilakukan 
Ahmed dkk mengenai kematian ibu pengalaman Rumah Sakit tersier di Mesir Bagian Atas menyebutkan rasio kematian ibu menurun secara progresif 2009-2014. Selain itu, menemukan bahwa penyebab tidak langsung kematian ibu melahirkan sebanyak $24,9 \%$ dari semua kematian. Mengenai penyebab langsung kematian ibu, preeklampsia tetap menjadi penyebab utama (Ahmeddkk, 2016).

Menurut WHO (World Health Organization) tahun 2014 angka kematian ibu di dunia sebanyak 289.000 jiwa dan memperkirakan 800 perempuan meninggal setiap harinya akbiat komplikasi kehamilan dan proses kelahiran. Sekitar 99\% dari seluruh kematian ibu terjadi di negara berkembang. Sekitar $80 \%$ kematian maternal merupakan akibat meningkatnya komplikasi selama kehamilan, persalinan dan masa nifas (WHO, 2014).Kematian wanita usia subur disebabkan oleh masalah yang berkaitan dengan kehamilan, persalinan serta nifas. WHO memperkirakan diseluruh dunia setiap tahunnya lebih dari 585.000 meninggal karena komplikasi kehamilan, persalinan, dan nifas (WHO,2014).

Peningkatan kesehatan ibu dan bayi di Indonesia adalah salah satu komitmen Depkes melalui penerapan rencana pengurangan Angka Kematian Ibu (AKI) dan Angka Kematian Bayi (AKB). Penurunan Angka Kematian Ibu per 100.000 kelahiran hidup masih terlalu lamban untuk mencapai target Indonesia sehat 2010 dan tujuan MDGs (Millenium Development Goals) tahun 2015 yaitu 102 per 100.000 kelahiran hidup (WHO 2012). Laporan Survey Demografi Kesehatan Indonesia (SDKI) menyebutkan Angka Kematian Ibu pada tahun 2012 di Indonesia mencapai 359 per 100.000 kelahiran hidup (SDKI, 2012).Preeklampsia berat ialah salah satu penyebab utama kematian ibu di indonesia, sebagaimana penelitian yang dilakukan oleh nova muhani dan besral tentang preeklampsia berat dan kematian ibu di RSUD Dr. H. Abdul Moeloek lampung. Data diolah dari rekam medis rumah sakit selama periode lima tahun (2010-2014). Bahwa penyebab kematian ibu diantaranya eklampsia, sindrom HELLP, tekanan darah diastolik dan sistolik. Ibu yang mengalami kejang atau eklampsia memiliki risiko kematian ibu 12,1 kali lebih tinggi dan ibu yang mengalami sindrom HELLP memiliki risiko kematian 12,5 kali lebih tinggi.

Pada ibu dengan tekanan darah sistolik $190 \mathrm{mmHg}$ atau lebih memiliki risiko kematian ibu 2,1 kali lebih tinggi dan tekanan darah sistolik 170-189 $\mathrm{mmHg}$ atau memiliki risiko kematian ibu 1,6 kali lebih tinggi dibandingkan dengan tekanan darah sistolik 140-169 mmHg. Serta tekanan darah diastolik $120 \mathrm{mmHg}$ atau lebih memiliki risiko kematian ibu 7,4 kali lebih besar dan tekanan darah diastolik 110-119 mmHg memiliki risiko kematian ibu. 
5,5 kali lebih besar dibandingkan dengan diastolik 140-169 mmHg. Ibu dengan preeklampsia berat dengan proteinuria +2 memiliki risiko kematian 2,1 kali lebih tinggi, proteinuria +3 memiliki risiko kematian 4,2 kali lebih tinggi dan proteinuria +4 memiliki risiko kematian 3,2 kali lebih tinggi dibandingkan dengan proteinuria +1 (Nova Nurani, 2015). Berdasarkan data yang di peroleh dari Dinas Kesehatan Provinsi Sulawesi Selatan pada tahun 2016, AKI mencapai 153 orang per 100.000 kelahiran hidup, sedangkan AKB terbanyak (48\%) terjadi pada bulan pertama atau masa neonatus dan penyebab terbanyak (44\%) kematian ibu adalah preeklampsia (Profil DINKES Sul-Sel, 2016).

Di Sulawesi Selatan penyebab langsung kematian ibu adalah hipertensi, hal ini berdasarkan pada penelitian yang dilakukan oleh Ansariadi tentang Epidemologi kematian ibu di Sulawesi-Selatan 2008-2013 menunjukkan bahwa 61\% (15kabupaten) di SulawesiSelatan mengalami penurunan MMR pada tahun 2013. Peningkatan dan penurunan MMR tersebut bervariasi antar kabupaten. Pada tahun 2013, hanya 6 kabupaten yang memiliki MMR diatas 100 per 100.000 kelahiran hidup. Hasil spatial analisis menunjukkan bahwa kenaikan MMR terjadi pada kabupten di wilayah bagian tengah sulawesi-selatan. Pola penyebab langsung kematian maternal mengalami perubahan selama lima tahun terakhir. Pada tahun 2013 kematian karena hipetensi menjadi penyebab utama kematian ibu yaitu $38 \%$, sedangkan perdarahan menempati urutan kedua yaitu $30 \%$. Selain itu terdapat variasi penyebab kematian ibu pada tingkat kabupaten (Ansariadi, 2014).

Berdasarkan data yang diperoleh dari Rekam Medik Rumah Sakit Syekh Yusuf Kabupaten Gowa menunjukkan jumlah persalinan pada periode 2013 yaitu 246 persalinan terdapat 71 kasus persalinan preeklampsia. Pada tahun 2014 yaitu 398 persalinan terdapat 18 kasus persalinan dengan preeklampsia. Tahun 2015 yaitu 1.011 persalinan terdapat 21 kasus persalinan dengan preeklampsia. Tahun 2016 yaitu 1.143 persalinan terdapat 14 kasus persalinan dengan preeklampsia. dan pada tahun 2017 yaitu 558 persalinan terdapat 18 kasus persalinan dengan preeklampsia. Jumlah persalinan secara keseluruhan mulai tahun 2013 2017.

Berdasarkan standar kompetensi bidan pada persalinan yaitu standar kompetensi ke-4 bidan memberikan asuhan yang bermutu tinggi, tanggap terhadap kebudayaan setempat selama persalinan, memimpin selama persalinan yang bersih dan aman, menangani situasi kegawatdaruratan untuk mengoptimalkan kesehatan wanita dan bayinya yang baru lahir serta 
memberikan dukungan moral kepada ibu dan keluarga untuk tetap berdoa dan bertawakkal kepada Allah SWT untuk kesembuhan ibu.

Berdasarkan masalah tersebut penulis tertarik untuk mengambil studi kasus dengan judul "Manajemen Asuhan Kebidanan Intranatal Berkelanjutan Pada Ny "M" Dengan Preeklampsia Berat Di RSUD Syekh Yusuf Kabupaten Gowa 2018”.

\section{METODE PENELITIAN}

Jenis penelitian ini adalah studi kasus dengan pendekatan manajemen asuhan kebidanan sesuai dengan 7 langkah Varney dan pendokumentasian dalam bentuk SOAP. Penatalaksanaan Asuhan dilakukan dengan pemberian asuhan yang sesuai standar operasional prosedur pada kasus yang diteliti yaitu persalinan dengan Preeklampsia berat serta melakukan upaya pencegahan komplikasi dengan pemberian Magnesium Sulfat untuk mencegah terjadinya eklampsia, HELLP Sindrom, solusio plasenta, gangguan organ, KJDR pada bayi serta dilakukannya pemantauan dan Asuhan Manejemen Kebidanan dari kala I sampai kala IV.

\section{HASIL PENELITIAN}

Penelitian ini dilakukan di RSUD Syekh Yusuf Kabupaten Gowa tepat dengan pembahasan tentang Manajemen Asuhan Kebidanan Intranatal Berkelanjutan pada Ny "M" dengan Preeklampsia Berat di RSUD Syekh Yusuf Kabupaten Gowa Tanggal 15 Oktober-21 November 2018. Pembahasan ini dibuat berdasarkan landasan teoritis dan studi kasus yang dapat dianalisa secara teoritis untuk memudahkan memahami kesenjangan dan kesesuaian yang terjadi pada kasus ini dengan berdasarkan pada pendekatan asuhan kebidanan dengan 7 langkah Varney yakni: pengumpulan data dasar, merumuskan diagnosis atau masalah potensial, melaksanakan tindakan segera atau kolaborasi, merencanakan tindakan asuhan kebidanan.

\section{Kala I}

Berdasarkan hasil pengkajian pada Ny "M" didapatkan data subjektif dan objektif menunjukkan bahwa diagnosis inpartu kala I fase aktif dengan preeklampsia berat. Hasil yang diperoleh pada kasus Ny "M" yakni pembukaan $6 \mathrm{~cm}$, terpasang infus RL serta didapatkan proteinuria +2 , keadaan ibu lemah dan janin baik. Dengan demikian seorang 
bidan harus tetap memberikan dukungan psikologis dan spiritual kepada ibu dan keluarga sangat penting agar tetap tenang dalam menghadapi persalinannya yaitu dengan memperbanyak berdo'a, berdzikir, istighfar, membacakan dan mendengarkan lantuan ayat suci Al-Qur'an.

\section{Kala II}

Pengkajian pada kala II pada kasus ny "M" didapatkan data subjektif Ibu mengatakan sakit kepala semakin kuat, ibu merasakan adanya dorongan kuat untuk meneran. Sedangkan data objektif didapatkan tampak perineum menonjol, vulva dan vagina membuka, pada pemeriksaan didapatkan pembukaan serviks telah lengkap. Pada kasus Ny "M" kala II berlangsung normal dan bayi lahir tanggal 15 oktober 2018 jam 12:55 WITA, dengan BCB dan keadaan bayi baik dengan berat badan lahir 3000 gram, panjang badan $49 \mathrm{~cm}$, tinggi fundus uteri setinggi pusat. Berdasarkan pengkajian yang telah dilakukan pada $\mathrm{Ny}$ "M" di kala II tidak ditemukan kesenjangan antara teori dan kasus.

\section{Kala III}

Pada kasus Ny "M" didapatkan hasil pemeriksaan dalam keadaan normal ditandai dengan uterus teraba keras dan bundar, tinggi fundus uteri setinggi pusat yang berarti kala III berlangsung normal, serta tidak ada kesenjangan antara teori dan praktej yang dilakukan.

\section{Kala IV}

Pada kasus Ny "M" didapatkan kontraksi uterus baik teraba keras dan bundar, tinggi fundus uteri setinggi pusat, kandung kemih kosong, jumlah perdarahan $\pm 250 \mathrm{cc}$, tekanan darah 150/100 mmHg.hasil evaluasi ini membuktikan bahwa kala IV berlangsung normal dan tidak ada kesenjangan antara teori dan praktek.

\section{PEMBAHASAN}

\section{Kala I}

Pada langkah 1 ini dilakukan pengkajian dengan mengumpulkan semua data yang diperlukan untuk mengevaluasi klien secara lengkap. Teknik pengumpulan data ada tiga yaitu: Observasi, Wawancara dan pemeriksaan, secara garis besar diklasifikasikan sebagai data subjektif dan objektif. Maka dari itu dibutuhkan anamnesa terhadap klien seperti 
melakukan tanya jawab kepada ibu untuk memperoleh data meliputi riwayat kesehatan, riwayat reproduksi, riwayat menstruasi, riwayat obstetrik, riwayat kehamilan, persalinan dan nifas, riwayat ginekologi, riwayat $\mathrm{KB}$, riwayat pemenuhan kebutuhan dasar, data sosial ekonomi dan psikologi. Tindakan yang pertama kali dilakukan di RSUD Syekh Yusuf yakni pengumpulan data subjektif yang terdiri dari alasan utama ibu masuk ke Rumah Sakit, riwayat keluhan utama, riwayat menstruasi, riwayat perkawinan, riwayat kehamilan sekarang, riwayat kehamilan dan persalinan yang lalu, riwayat nifas yang lalu, riwayat kesehatan sekarang dan yang lalu, riwayat penyakit keluarga, riwayat sosial ekonomi, psikososial, dan spiritual, riwayat KB, serta riwayat kebutuhan dadar ibu. Sementara itu, dilakukan pula pengumpulan data secara objektif yang terdiri dari pemeriksaan umum ibu, pemeriksaan fisik (Headtotoe), dan pemeriksaan dalam serta pemeriksaan laboratorium.

Berdasarkan penerapan asuhan kebidanan terhdap Ny "M" usia 37 tahun, GIII PII A0, datang ke rumah sakit pada pukul 08:40 WITA dengan keluhan nyeri pada perut bagian bawah yang disertai dengan adanya pelepasan lendir bercampur dengan darah sejak yanggal 15 Oktober 2018 pukul 03:00 WITA, dan rasa nyeri yang dirasakan oleh ibu hilang timbul dan semakin lama semakin sering dan bertambah kuat, tekanan darah didapatkan 150/100 $\mathrm{mmHg}$, pasien mengatakan selam hamil pergerakan janinnya kuat dan bergerak pada bagian sebelah kiri perut ibu, pasien mengatakan sering sesak karena tekanan pada fundusnya, pasien mengatakan melakukan kunjungan antenatal care (ANC) sebanyak 5, di Puskesmas Somba Opu, pasien mengatakan hari pertama haid terkahir tanggal 13 januari 2018, dan usia kehamilannya \pm 9 bulan, pasien mengatakan selama hamil ia tidak pernah merasakan nyeri perut yang hebat, terpasang infus MgSO4 40\% 20 tetes/menit dalam $500 \mathrm{cc}$ RL, terdapt oedema pada ektremitas bawah serta pemeriksaan laboratorium dan didaptkan proteinuria +2 .

Pasien tidak pernah mengalami trauma selama kehamilan yang sekarang maupun kehamilan yang lalu, pasien tidak memiliki riwayat penyakit seperti hipertensi, asma, jantung, diabetes dan penyakit menular lainnya, pasien mengatakan pernah menjadi akseptor kb suntik 3 bulan selama 3 tahun, nutrisi pasien terpenuhi dengan baik, istirahat cukup, aktivitas pasien tetap melakukan pekerjaan rumah tangga.

Nyeri perut yang terjadi karena terbukanya mulut rahim disertai peregangan otot polos rahim yang menimbulkan nyeri karena adanya penekanan pada ujung syaraf sewaktu uterus berkontraksi. Kontraksi uterus yang terjadi secara teratur dan teraba portio lunak dan tipis serta pembukaan $6 \mathrm{~cm}$ merupakan kala I fase aktif yang dimulai dari pembukaan 4-10 cm. 
Di dalam kehamilan, janin dikatakan tunggal jika pembesaran perut sesuai dengan usia kehamilan. Saat palpasi teraba satu kepala dan satu punggung, dan auskultasi denyut jantung janin terdengar jelas, kuat dan teratur pada satu kuadran perut ibu (Oktarina, 2016:9).Ibu yang mengalami komplikasi-komplikasi pada persalinan salah satunya preeklampsia berat.Preeklampsia berat adalah preeklampsia dengan tekanan darah sistolik $\geq 160 \mathrm{mmHg}$ dan tekanan darah diastolik . $\geq 110 \mathrm{mmHg}$ disertai proteinuria lebih dari +2 (Sarwono, 2014).

\section{Kala II}

Berdasarkan pengkajian pada kasus Ny "M" kala II berlangsung dengan normal yaitu 15 menit dan bayi lahir spontan tanggal 15 oktober 2018, jam 12:55 WITA, dengan berat badan lahir 3000 gram, panjang badan $49 \mathrm{~cm}$, apgar score 8/10, jenis kelamin laki-laki, kontrkasi uterus teraba keras dan bundar, TFU setinggi pusat. Sesuai dengan teori yang menyebutkan kala 2 normal jika prosesnya berlangsung selama 2 jam pada primigravida dan 1 jam pada multigravida (Kuswanti, 2016). pada persalinan dengan preeklampsia berat, penyulit pada janin ialah intrauterine fetal growth restriction, solusio plasenta, prematuritas, sindrom distres napas, kematian janin intrauterin, kematian neonatal (Walyani, 2015).

Dalam hal ini antisipasi kemungkinan masalah yang akan terjadi. Dalam penelitian sebelumnya menyebutkan masalah potensial yang mungkin terjadi pada ibu dengan preeklampsia berat adalah kejang-kejang (eklampsia), HELLPP sindrom, solusio plasenta, perdarahan otak, gangguan organ (Ralph dkk, 2013). Dan pada bayi terjadi gawat janin, asfiksia, dan kematian janin (Sarwono, 2014).Persalinan pada kasus preeklampsia berat mengakibatkan terjadinya eklampsia yang dimana eklampsia merupakan jenis kejang otot yang dapat dialami wanita hamil, biasanya dari usia kehamilan 20 minggu atau beberapa waktu setelah melahirkan. Selama kejang eklampsia, lengan, kaki, leher, atau rahang tanpa sadar akan berkedut berulang kali kejang biasanya berlangsung kurang dari satu menit. Meski kebanyakan wanita dapat pulih setelah eklampsia, namun ada risiko terjadi cacat permanen atau kerusakan otak jika mengalami kejang parah (Ralph dkk, 2013).

Berdasarkan pengkajian pada kasus Ny "M" kala II berlangsung dengan normal yaitu 15 menit dan bayi lahir spontan tanggal 15 oktober 2018, jam 12:55 WITA, dengan berat badan lahir 3000 gram, panjang badan $49 \mathrm{~cm}$, apgar score 8/10, jenis kelamin laki-laki, kontrkasi uterus teraba keras dan bundar, TFU setinggi pusat. Sesuai dengan teori yang menyebutkan kala 2 normal jika prosesnya berlangsung selama 2 jam pada primigravida dan 
1 jam pada multigravida (Kuswanti, 2016). pada persalinan dengan preeklampsia berat, penyulit pada janin ialah intrauterine fetal growth restriction, solusio plasenta, prematuritas, sindrom distres napas, kematian janin intrauterin, kematian neonatal (Walyani, 2015).

\section{Kala III}

Pada kasus Ny "M" didapatkan hasil pemeriksaan dalam keadaan normal ditandai dengan uterus teraba keras dan bundar, tinggi fundus uteri setinggi pusat yang berarti kala III berlangsung normal, serta tidak ada kesenjangan antara teori dan praktek yang dilakukan. Berdasarkan teori yang didapatkan asuhan persalinan kala III dimulai segera setelah bayi lahir sampai lahirnya plasenta yang berlangsung tidak lebih dari 30 menit. Setelah bayi lahir uterus teraba kerasa dengan fundus uteri agak di atas pusat untuk melepaskan plasenta dari dindingnya. Tanda-tanda terlepasnya plasenta yaitu perubahan bentuk dan tinggi fundus uteri, tali pusat memanjang, tali pusat terlihat menjulur keluar melalui vulva, semburan darah tibatiba (Walyani, 2015).

Pada kasus Ny “m” dilakukan intervensi yang sesuai yaitu pemberian oksitosin, peregangan tali pusat dan masase uterus. Periksa tinggi fundus uteri untuk memastikan tidak ada janin, pemberian oksitosin dilakukan setelah 1 menit bayi lahir. Setelah itu, suntikkan oksitosin secara IM di sepertiga bagian atas paha ibu dan segera lakukan IMD.Pada kasus Ny 'M' melakukan pemberian oksitosin secara IM, kemudian melakukan peregangan tali pusat terkendali untuk melahirkan plasenta, lakukan masase uterus setelah plasenta lahir. Proses pelepasan dan pengeluaran plasenta berlangsung normal tanpa penyulit. Plasenta lahir 5 menit setelah bayi lahir yaitu jam 13:00 WITA, plasenta lahir lengkap dengan ketiledon dan selaput ketuban utuh, perdarahn $\pm 250 \mathrm{cc}$ dan segera dilakukan IMD. Dari implementasi yang telah dilakukan pada kasus Ny "M" didapatkan hasil pemeriksaan TTV ibu didapatkan TD 150/100 mmHg dan masih terpasang infus MgSO4, kontrkasi uterus baik ditandai dengan uterus teraba keras dan bundar, tinggi fundus uteri setinggi pusat, sehingga kala III berlangsung normal, serta tidak ada kesenjangan anatara teori dengan praktek.

\section{Kala IV}

Berdasarkan teori pada kala IV hal-hal yang harus diperhatikan yaitu kontraksi uterus baik, pemeriksaan serviks, vagina dan perineum hal ini berguna untuk mengetahui terjadinya laserasi (adanya robekan) yang dapat diketahui dari adanya perdarahan pasca persalinan tanda 
- tanda vital, keadaan ibu dan keadaan janin (Kuswanti, 2014). Pada kasus Ny "M" didapatkan bahwa TD 150/100 mmHg, kontaksi uterus baik, teraba keras dan bundar, tinggi fundus uteri setinggi pusat, kandung kemih kosong, jumlah perdarahan $\pm 70 \mathrm{cc}$, hasil evaluasi tersebut menunjukkan bahwa kala IV berlangsung normal dan tidak ada penyulit serta tidak ada kesenjangan antara teori dengan praktek.

Teori mengatakan sebagian besar kematian ibu pada periode pasca persalinan terjadi 6 jam pertama setelah persalinan, kematian itu disebabkan oleh infeksi, perdarahan dan eklampsia. Oleh karena itu, pemantauan selama 2 jam pertama post partum sangat penting (Saleha, 2013).Berdasarkan teori yang ada dan data pada kasus yang ada menunjukkan bahwa tidak ada kesenjangan teori dan praktek yang dilakukan.

\section{KESIMPULAN DAN SARAN}

\section{A. KESIMPULAN}

1. Telah dilakukan pengkajian dan analisis data dasar pada Ny "M" dengan preeklampsia berat pada persalinan di RSUD Syekh Yusuf tahun 2018. Pada kasus Ny. "M" didapatkan data dasar dengan tekanan darah 150/100 mmHg dan proteinuria +2 .

2. Telah dilakukan pengidentifikasian diagnosa/ masalah aktual pada Ny "M" dengan preeklampsia berat pada persalinan di RSUD Syekh Yusuf Gowa Ny. "M" masuk dengan tanda dan gelaja inpartu dan keluhan lain yang menyertai pusing pada kepala dan merasa lemas.

3. Telah dilakukan pengidentifikasian diagnosa/ masalah potensial pada Ny " $\mathrm{M}$ " dengan preeklampsia berat pada persalinan di RSUD Syekh Yusuf Gowa diantisipasi terjadinya eklampsia, HEELLP sindrom, solusio plasenta, KJDR.

4. Telah dilakukan tindakan segera dan kolaborasi pada Ny "M" dengan preeklampsia berat pada persalinan di RSUD Syekh Yususf. Kolaborasi dilakukan bersama dokter obgyne untuk tindakan pencegahan.

5. Telah dilakukan penyusuanan rencana tindakan asuhan kebidanan pada Ny "M" dengan preeklampsia berat pada persalian di RSUD Syekh Yususf Gowa tahun 2018. Intervensi dilakukan dengan pemantaauan persalinan dengan partograf, pemasangan 
infuse 4 gram MgSO4 40\% 28 tetes/menut selama 6 jam dalam 500 cc Ringer Laktat, perencanaan persalinan dengan hati-hati.

6. Telah dilakukan tindakan asuhan kebidanan pada Ny "M" dengan preeklampsia berat pada persalian di RSUD Syekh Yususf Gowa tahun 2018. Telah dilakukan sesuai dengan intervensi, bayi lahir pada pukul 12.55 wita berjenis kelamin laki-laki, berat badan lahir 3000 gram, panjang badan $49 \mathrm{~cm}$ dan apgar skor 8/10.

7. Telah dilakukan evaluasi asuhan kebidana pada Ny "M" dengan Preeklampsia berat pada persaalinan di RSUD Syekh Yususf tahun 2018. Kondisi ibu baik dan tidak terjadi perdarahan post partum.

8. Pendokumentasian dilaksanakan mulai tanggal 15 okotber-21 November 2018.

\section{B. SARAN}

1. Meningkatkan upaya pencegahan terjadinya preeklampsia berat pada persalinan dengan pelayanan antenatal care yang sesuai standar.

2. Mengenali sedini mungkin komplikasi-komplikasi pada kehamilan dan upaya penanganan.

3. Melakukan pertolongan preeklampsia berat pada persalinan dengan baik yaitu salah satunya dengan menjalin hubungan saling percaya yang baik dengan pasien, keluarga pasien dan tenaga kesehatan lain.

\section{DAFTAR PUSTAKA}

Ansariadi, 2014. Epidemologi Kematian Ibu di Sulawesi-Selatan 2008-2013. Yogyakarta: Jurnal Departemen Epidemologi http://respository.unhas.ac.id.

Abbas, AM, dkk, 2016. Maternal Mortality a tertiary care hospital experience in Upper Egypt. Egypt: Journal International.

Ai Yeyeh Rukiyah, Lia yulianti, Asuhan Kebidanan 4 (patologi), Jakarta: TIM, 2010

Anita Dewi L, Dkk. Jurnal Kebidanan dan Ilmu Kesehatan Volume 3/ Nomor 1/ April 2016.Gambaran Karakteristik Ibu Bersalin Dengan Preeklamsi di RSU Assalam Gemolong Sragen.

Abu Bahru. Terjemah tafsir Al-Maraghi, Vol 17, Semarang: PT Karya Putra Toha, 2003.

Betsy B. Dkk, Modul Manajemen Intrapartum, Penerbit Buku Kedokteran, 2014 
Departemen Agama RI. 2012. Al-qur'an Tajwid dan Terjemahan. CV : Penerbit Diponegoro

Hinda Vovianti: Jurnal Ilmiah Kesehatan Vol, 9 No,1, Februari 2016, Hal 25-31. Pengaruh Usia dan Paritas Terhadap Kejadian Preeklampsia Di RSUD Sidoarjo.

Katsir Ibnu, Syaikh dkk. Shahih Tafsir Ibnu Katsir, Jilid 5. Jakarta: Pustaka Imam Asy-Syafit I, 2003.

Kuswanti, Ina. Melina Fitriani, Askeb II Persalinan, Yogyakarta: Pustaka Pelajar, 2016.

Mondal, Suresh Candra, dkk, 2014. Earliest Use of Medical Prophylactic Dose of Magnesium Sulphate (mgso4) in Severe Pre-eclampsia ti Improve Maternal And Perinata Outcome in a Rural Medical Collage, WB India.

Nurhayati, dkk. Konsep Kebidanan. Jakarta: Salemba Medika, 2013

Nova Nuhani. Jurnal kesehatan masyarakat Vol.10 no.2 November 2015. Preeklampsia berat dan kematian ibu.

Novita Lusiana. Jurnal Nasional.Faktor-faktor yang berhubungan dengan kejadian Preeklampsia pada ibu bersalin di RSUD Arifin Achmad Provensi Riau 2014.

Norma nita dan mustika, Asuhan kebidanan patologi, Yogyakarta: Nuha Medika, 2013

Natiqotul Fatkhiyah, Dkk. Jurnal Keperawatan Soedirman (The Soedirman Jurnal Of Nursing), Volume 11, No,1 Maret 2016. Determinan Maternal kejadian Preeklampsia (Studi Kasus Di Kabupaten Tegal, Jawah Tengah).

Oktarina, Mika. Buku Ajar Asuhan Kebidanan Persalinan Dan Bayi Baru Lahir, Yogyakarta: Deepublish, 2016.

Penuntun Penulisan KTI UIN: Makassar- Samata Gowa: UIN Press, 2013

Profil Kesehatan Prov. Sulsel tahun 2016

Roboson, Elizabeth. S dan Jason Waugh, Patologi pada Kehamilan Manjemen dan Asuhan Kebidanan, Jakarta: EGC, 2013.

Prawihardjo, Sarwono. Ilmu Kebidanan. Jakarta: Bina Pustaka Sarwono Prawihardjo, 2014.

Ralph C. Benson dan Martin L. Pernoll, Obstetru dan Ginekologi. Penerbit Buku Kedokteran: 2013.

Riyanti Imron, Dkk: Jurnal Keperawatan, Volume x, No,1 April 2014.Faktor Yang Berhubungan Dengan Kejadian Preeklampsia dan Eklampsia Pada Ibu Bersalin. 
Rien A. Hutabarat, Dkk: Jurnal e-clinic (eCl), Volume 4, Nomor1, Januari-Juli 2016. Karakteristik Pasien dengan Preeklampsia di RSUP Prof. Dr. R. D. Kandou Manado.

Rekam Medik Rumah Sakit Umum Daerah Syekh Yusuf 2017

Shihab,M. Quraish. Pesan, kesan, dan Keserasian Al-qur'an (Tafsir Al-Misbah). Jakarta: Lentera Hati, 2009.

SDKI (Survey Demografi Kesehatan Indonesia). 2012. Angka Kematian Ibu AKI Indonesia www.Depkes.co.id

Saleha, Sitti. Asuhan Kebidanan Pada Masa Nifas, Jakarta: Salemba Madika, 2013.

Suriani Tahir, Dkk: Jurnal Voice Of Midwifery, Vol,07 No,09 september 2017.Faktor Risiko Terjadinya Preeklampsia Berat Di RSUD Syekh Yusuf Gowa.

Siqbal Karta. A. Dkk. Jurnal Kesehatan Andalas, 2016:513. Hubungan Usia Dan Paritas Dengan Kejadian Preeklampsia Berat Di Rumah Sakit Achmad Bukittinggi Tahun 2012-2013.

Sandi Ramadhani, dkk:/Jurnal Manajemen Informatika, Volume 03 Nomor 02 Tahun 2014, 17-25.Rancang Bangun Sistem Pakar Untuk Mendiagnosa penyakit Degeneratif.

WHO, Buku Saku Pelayanan Kesehatan Ibu Di Fasilitas Kesehatan Dasar Dan Rujukan, Edisi Pertama, Jakarta, 2013.

Walyani, Proastuti. Asuhan Kebidanan Persalinan Dan Bayi Baru Lahir, Yogyakarta: Pustaka Medika, 2015.

Yulifah, Rita dan Surachmindari.Konsep Kebidanan Untuk Pendidikan Kebidanan. Jakarta Selatan: Salemba medika, 2013

Yulia Fauziyah. Obstetri patologi untuk mahasiswa kebidanan dan keperawatan, Cirebon: Nuha Medika, 2012. 